\title{
Conrad's Heart of Darkness and Achebe's Duplicity in Things Fall Apart and Arrow of God
}

\author{
Njeng Eric Sipyinyu \\ University of Burundi, Bujumbura, Burundi
}

\begin{abstract}
Achebe represents images of Africa in Things Fall Apart and Arrow of God that duplicates Conrad's portrait in Heart of Darkness. Conrad's Africa as an enigmatic dark spot is replicated in the works of Achebe, thereby, debunking popular critical polarizations of the texts. However, while Conrad's narrative engages a double indictment of representations of darkness in the consciousness of both Europe and Africa, Achebe simply surrenders to a one-sided condemnation of African traditions and acquiesces to western narratives. Ultimately, while Conrad's narrative leaves an echo of double reverberation in the heart of the reader, Achebe's provide closure in his evident installation of western ideologies and their institutions. Conrad's influence on Achebe is manifestly evident in Things Fall Apart (1958) and Arrow of God (1964). The fact that Achebe disavows this is an issue in this paper.
\end{abstract}

Keywords: Conrad, Heart of Darkness, Achebe, Things Fall Apart, Arrow of God, duplicity

\section{Introduction}

Chinua Achebe's Things Fall Apart (1958) is often placed against Joseph Conrad's Heart of Darkness (2007) as a counter discourse. Achebe himself confesses that his intention in writing Things Fall Apart was to situate it as a counter discourse. In his essay entitled "Named for Victoria, queen of England," he fosters this view when he clearly states, "Although I did not set out consciously in that solemn way I now know that my first book, Things Fall Apart, was an act of atonement with my past, a ritual return and homage of a prodigal son" (Achebe, 1995, p. 193). In another essay entitled "An image of Africa," Achebe takes issue with Conrad's Heart of Darkness, accusing Conrad of being a "bloody racist" (Achebe, 2000, p. 328).

Other critics, however, take a distance from Achebe's scathing attacks. Wilson Harris (2000) sympathised with Achebe's foreboding about Conrad's racist imagery in "The Frontier on which Heart of Darkness stands," but insisted that Conrad's creative thrust must have necessitated a dissection of the imperial agenda in those terms. Nevertheless, it was stroke of genius on his part to visualize an original necessity for distortions in the stases of appearance that seem sacred and that cultures take for granted as models of timeless dignity (p. 335). Corroborating Wilson, Harry Sewlall (2006, p. 7) interpellated Achebe's concern that Conrad denies Africans a voice in an essay entitled "Masquerading philanthropy: Conrad's image of Africa in 'An outpost of progress'." In a short story that predates Heart of Darkness entitled "An outpost of progress," Sewlall (2006) argued that the African is presented as one who is not only given a voice but who demands an identity and that of a white man to boot. Makola, the African colonial agent in the story is not only multi-lingual but capable of

Njeng Eric Sipyinyu, Ph.D., senior lecturer, Department of English Language and Literature, University of Burundi. 
manipulating white superiors and getting the upper hand. What is suggested by Harris and Sewlall is the fact that Achebe's attack on Conrad has to be re-considered.

The author counters criticism of Achebe that places his works as deconstructive of western narratives by inscribing an African culture that resisted and probably even could substitute western narratives. The author argues that Achebe's response to colonial narratives is seen in his anti-nomianism set against his disavowal of African traditional beliefs and practices. Neil Lazarus (2004, p. 7) posited Achebe as a leading writer who resists Western representations of Africa and its cultures, "Among the best known instances of such resistance are those offered by Chinua Achebe in his auto-ethnographic novel, Things Fall Apart." This is corroborated by John Marx who uses Simon Gikandi's claim that Things Fall Apart serves as a counterpoint to representations of African life provided by major figures in British literature, such as Haggard, Kipling, Conrad, and Greene (2004, p. 92). Other scholars have shown the same tendency of presenting Achebe as counterpoint to European ideologies. Douglas Killam and Ruth Rowe (2000, p. 3) revealed this misconception in their review of Things Fall Apart and Arrow of God when they state that, "By foregrounding the rituals and institutions for ordering the pre-colonial universe, the novels seek to rescue the people's history from the denigrating historiography by which the colonial enterprise had been rationalized." Such a critique overlooks the authorial advocacy of western ideologies as a counterpoint disestablishing African traditional practices akin to cannibalism. In Things Fall Apart, the inflexible macho protagonist is destroyed by the impending forces of colonial institutions, while in Arrow of God, the protagonist is destroyed by his espousal of the power evident in the colonial enterprise. The trajectories of both plots are an evident denunciation of African cultural practices and a proselytizing ideology that is clearly supported by Achebe.

\section{Conrad as a Father Figure to Achebe}

One cannot help but wonder the extent to which Conrad's Heart of Darkness might have served as an inspiration for Achebe in his crafting of Things Fall Apart and Arrow of God. There is no doubt that Achebe's initiation into the world of letters started with his readings of canonical works that included Conrad. Achebe's attack on Conrad functions as a confession, a guilt complex tormenting, and looking for a vent to purge itself. Writing in the appendix to Heart of Darkness, Conrad (2007, p. 112) declared his filiations with Great Britain thus,

It lies on me to confess at last and this is as good a place for it as another, that I have been all my life —all my two lives-the spoiled adopted child of Great Britain and even of the Empire.

Achebe's (2009) collection of essays is symbolically entitled "The education of a British-protected child" wherein he makes this comment, "To call my colonial experience an inheritance may surprise some people. But everything is grist to the mill of the artist" (p. 111). What is remarkable is their christening as British "adopted" in the case of Conrad and British "protected" in the case of Achebe. The former nationalized as a British citizen while the latter won the approval of Great Britain, which makes Conrad and Achebe siblings of sorts. The author's concern here is the attack Achebe levies against Conrad when one considers the parallels that unite these works in terms of representations of Africa and some of the stereotypes that inform Africa in the Western imagination. It may often appear easier for the subaltern subject to accuse the other of an Ism because of what may be considered the singular privileged position of the underdog. Subaltern groups, especially Africans, enjoy very little privileges and the privilege of dispossession is usually the only available. 
Achebe's narrative re-echoes major images of Africans which Conrad, as outsider, represents. Coming from an insider position, we argue that Achebe merely confirms Conrad, probably even mimics him. Harold Bloom (1974) contended that the artist is inspired to write by the work of a previous artist, who as a precursor, may be said to symbolically represent the father. Like with Freud's oedipal complex, the successor tries to eclipse the work of the precursor, both to outdo the "father" and gloss over the debt of influence. In the case of Achebe's oedipal anxiety to Conrad, he stands probably not as a legitimate, but as an illegitimate son making his anxiety even the more obvious. His kinship with Conrad is not direct like that of Conrad and Ford Maddox Ford. He is further removed and must build his sepulcher on the ruins of an illegitimate "father." By calling Conrad a "bloody racist," Achebe is attempting a complete dethronement of Conrad and his own enthronement. However, blood runs thicker than water as a careful analysis reveals striking simulacra in the works by both writers under consideration.

By daguerreotype, the author means similitude in representative imagery in the works of Conrad and Achebe. Here, Achebe is following the path set by Conrad in representing Africa with almost exact similitude. By duplicity, the author makes the argument that Achebe mimics Conrad given the similitude that their works portray. In his works, there is a replication of Conrad especially in representations of popular stereotypes of the late 19th and early 20th century. Writing on the canonical founding fathers of the English tradition, Edward W. Said (2003, p. 24) took issue with attacks of the like of Achebe's when he argues that,

The special point I then try to make is that it is imperative to read them as intrinsically worthwhile for today's non-European or non-Western reader, who is often either happy to dismiss them altogether as dehumanizing or insufficiently aware of the colonized people (as Chinua Achebe does with Conrad's portrayal of Africa), or reads them, in a way, "above" the historical circumstances of which they were so much a part. ... I see them contrapuntally, that is, as figures whose writing travels across temporal, cultural and ideological boundaries in unforeseen ways to emerge as part of a new ensemble along with later history and subsequent art.

Here, Said (2003) was striking a note against the scathing criticism Achebe levies against Conrad in an essay entitled "An image of Africa," paradoxically underscoring the potential for influence that informs Conrad's work. This influence could not have escaped the budding Achebe in his nurture and subsequent literary production.

\section{Replication of Historical Period}

A central aspect that unites these works is the historical periods in which they are set. Most critics situate the settings of Things Fall Apart and Arrow of God in the early years of the 20th century. Curiously, this is the period Conrad made his tour of Africa. In Conrad's "The Congo diary," the first entry is "arrived Matadi on the 13th of June, 1890." Their portraits cannot help but be similar given that their settings are around the equatorial forest and that both imbibed and recorded with the influence of currents that were to inform the next half century. Emmanuel Akyeampong (2014, p. 71) underscored this fact when he explains how Achebe's novels have served him "for years to provide undergraduate students with an understanding of a West African society in the late 19th and early 20th centuries encountering Christian missionaries and the imposition of colonial rule." If the novels have to actually serve their artistic roles, they cannot help but reveal the processes that allowed colonization to implant itself and dominate Africa for years to come. In this bid, Akyeampong (2014) suggested that the novel Things Fall Apart holds the reader in a double bind as he/she empathizes with the hero. At the same time, he witnesses the failings that characterized the society, "The reader empathizes with Okonkwo in Things fall Apart, regrets the corrosive effects of missionaries, and potentially loses sight of the fact that the 
crises that ground the novel were reflections within the tensions in Igbo society itself' (p. 71). These tensions are what make the daguerreotypes that the author exposes as replications of those in Conrad.

\section{Decapitaion and Anthropophagi Daguereotypes}

Central to the plots of the two writers are decapitation and anthropophagi daguerreotypes, which play central roles in determining the overarching themes in both writers. The dawn of the 20th century witnessed not just the impunity of colonial domination that involved arbitrary killings of indigenous populations, but also stereotypes that bestialized indigenous peoples. Conrad and Achebe both portray this in their works with sometimes striking parallels that suggest that one influenced the other. As Marlow moves deeper into the heart of the Congo, he comes across a shocking image of the authoritarianism of the colonial enterprise and displays his shock thus,

I was not so shocked as you may think. The start back I had given was nothing but a movement of surprise, I had expected to see a knob of wood there, you know. I returned deliberately to the first I had seen and there was a, black, dried, sunken, with closed eyelids head that seemed to sleep at the top of that pole, and, with the shrunken dry lip showing a narrow white line of teeth, was smiling too, smiling continuously at some endless and jocose dream of the eternal slumber. (pp. 71-72)

Here, we witness a horrible image of decapitated heads smiling at the onlooker who happens here to be in league with the murderer. The heads are dead but the smile that lingers on their lips is derisive of the enterprise that has cut short their lives with impunity.

The smiling skulls are a critique of the arbitrariness of the colonial enterprise as succinctly summed up in the words of Mbembe (2001, p. 26), "The lack of justice of the means and the lack of legitimacy of the ends conspired to allow an arbitrariness and intrinsic unconditionality that may be said to have been the distinctive feature of colonial sovereignty." This image of decapitation is numerously replicated in Things Fall Apart but this time the image of decapitation is not condemned but celebrated. Moreover, it is not aimed against the colonialism but presented to suggest that impunity also characterized pre-colonial African societies. Achebe presents the hero, Okonkwo, in a light that initially appears positive but the course of events will chastise and exclude him as his failings become evident.

He was a man of action, a man of war. Unlike his father, he could stand the look of blood. In Umuofia's latest war, he was the first to bring home a human head. That was his fifth head and he was not an old man yet. (p. 8)

Whereas Conrad stops short at showing us the heads hanging from a pole, Achebe takes the liberty to picture graphic images of cold-blooded infanticide. If Conrad tries to suggest the barbarism taking place in Africa as a complex involving both parties Achebe enhances this by giving graphic scenes of African barbarism, "He heard Ikemefuna cry, 'My father, they have killed me' as he ran towards him. Dazed with fear, Okonkwo drew his matchet and cut him. He was afraid of being thought weak" (p. 43). Njeng (2013) had drawn attention to these details and many others like the throwing of twins in the forest to bolster the argument that Achebe indicts traditional African customs and recommends change in the invitation of Christianity. In all, we see the hero kill three humans in the novel-Ikemefuna in an act of ruthless infanticide, a lad he carelessly murders, and a messenger that he again beheads.

Davidson B. (1992, p. 84) commented on this impunity in pre-colonial African societies when he states that, 
Homicide is a crime, but the killing of one person may not be answered by the killing of the killer. It may be better answered by providing the deprived family with a person to take the place of the lost person.

This is the case of Ikemefuna and the virgin who are given by the people of Mbaino to compensate for the killing of a member of Umuofia. Here, the killing of one human is paid for not by one replacement but two. The virgin is to serve as a wife to the bereaved husband and the lad is to be sacrificed to atone for the sacrilege committed by the killing. In all, we can say that Okonkwo beheads seven people. The author is of the opinion that Achebe simply extends Conrad's narrative by giving an insider account of the atrocities and the confusion that embattled Africa. One cannot help but notice that Conrad as outsider does everything to put a distance between himself and the narrators who are also careful to indicate when they are fully conscious of a phenomenon and when they are only half aware. Roland Barthes (1994, p. 223) upholded the view that the author is not the ultimate meaning of the text in his essay entitled "The death of the author." He portended to write, "The making of the narrator not he who has seen and felt nor even he who is writing, but he who is going to write." Most often, Marlow makes it clear that he sees most of the happenings through second hand accounts that are half true. Achebe in his stead makes no such distinction between fact and rumor. If Achebe (2000) wished the West to view Africans as civilized, then his portrait of cannibalism does not help.

To look at Africa not through a haze of distortions and cheap mystifications, but quite simply as a continent of people — not angels, but not rudimentary souls either - just people, often highly gifted people and often strikingly successful in their enterprise with life and society. (p. 12)

As a member of the society that Conrad is careful to describe as outsider, he does far more than confirm the images that are only suggested in Conrad's work. This savagery among the Umuofia is exacerbated by what probably comes close to a genocidal urge in the novel when the village as a whole comes together and attribute to the Christians the evil forest as a place to build their church. The underlying demonic wish is to have the Christians perish collectively. We see this popular impulse to annihilate when the Christians ask for a piece of land and the people collectively decide to lead the missionaries to their death by giving them the evil forest,

An evil forest was, therefore, alive with sinister forces and powers of darkness. It was such a forest that the rulers of Mbanta gave the missionaries. They did not really want them in their clan, and so they made them the offer which nobody in his right senses could accept. (p. 107)

That the annihilation of Christians does not come to pass in part is responsible for the preponderance of Christian converts who realize the God of the new religion is far superior to traditional deities. At the close of the novel, Christianity assumes ascendancy over traditional religion. The light drives away darkness.

Closely connected to the decapitation, daguerreotype is anthropophagi daguerreotype. Conrad's Marlow suggests the anthropophagous character of Africans, but does not furnish the reader graphic images of the actual consumption of human flesh. The Africans on the steamer have rotten hippo meat which serves as their staple but it ends there. The suggestion that they might literally eat human flesh occurs in an instance where they are under attack from a hostile tribe and one of them says, "Catch 'im. Give 'im to us. 'to you eh?' I asked. 'what would you do with them?' 'eat 'im' he said, curtly, and leaning his elbow on the rail (Catch him and give him to us. What would you do with him? Eat him! he said, as he looked out into the fog. I would have been horrified, but it occurred to me that the natives onboard must have been very hungry)" (p. 49). Alex Shoumatoff (1998) had shown this tendency of eating captives in some areas of Africa as part of a cultural ritual. Achebe does not seem to be disturbed by this image in Conrad's narrative. No doubt he goes even further 
by showing how Okonkwo drinks from the skull of one of his war captives without even the least horror, "On great occasions such as the funeral of a village celebrity he drank his palm-wine from his first human head" (p. 8). What strikes me forcefully here is that both writers image the decapitation of humans as signs of power and domination, but while one exhibits shock the other simply glosses over what can be argued as an act of cannibalism. Marlowe's shock in beholding the savagery of his own is registered in the horror that he exercises and Achebe's narrator exhibits no shock at an act of anthropophagi. Is Achebe here simply underscoring the stereotype that Africans incidentally resorted to acts of cannibalism or is he just being true to the facts of Ibo culture? This is troubling when one connects this image to popular critiques of Achebe as a counterpoint to Conrad.

\section{Africa as Darkness}

In both writers, images of darkness in forests and terrain that bespeaks evil forces abound. In Things Fall Apart, evil forest is the name of a spectral character that administers terror and justice. When one connects this to the evil forest where twins are left to perish and where the sick like Unoka are abandoned to die one begins to wonder what kind of justice can emanate from fear. Achebe is here undercutting the irony between justice and injustice. The description Conrad gives the fetish character of Africans would seem to reader as very authentic when one places it parallel to that of Achebe. As he moves up the river Congo towards the hero Kurtz, Marlow observes the natives in their traditional fashion thus,

In front of the first rank, along the river, three men, plastered with bright red earth from head to foot, strutted to and fro restlessly. When we came abreast again, they faced the river, stamped their feet, nodded their horned heads, swayed their scarlet bodies; they shook towards the fierce river-demon a bunch of black feathers, a mangy skin with a pendant tail - something that looked like a dried gourd; they shouted periodically together strings of amazing words that resembled no sounds of human language and the deep murmur of the crowd, interrupted suddenly, were like the responses of some satanic litany. (pp. 83-84)

If any reader is here shocked by this representation by Conrad, he does not have to go far to see an exact simulacrum in Things Fall Apart as Achebe describes what is supposedly a court proceeding, while underscoring the absence of justice as the judges seem to produce more terror than honour. In this instance, the judges of Umuofia appear not in human, but in spirit form to settle a domestic problem between husband and wife. Their appearance however is spectrally exotic and the judges inspire fear rather than trust in the populace. Their sudden appearance is described thus,

An iron gong sounded, setting up a wave of expectation in the crowd. Everyone looked in the direction of the egwugwu house. Gome, gome, gome, gome went the gong, and a powerful flute blew a hitched-pitched blast. Then, came the voices of the egwugwu, guttural, and awesome. The wave struck the women and children and there was a backward stampede. But it was momentarily. They were already far enough where they stood and there was room for running away if any of the egwugwu should go towards them. ... Their leader was Evil Forest. Smoke poured out of his head. (pp. 63-64)

This method of linking justice and the supernatural is evident in Arrow of God where the hero, Ezeulu, is also a mask as he is supposed to be half man and half god. His metaphysical nature is explained thus,

Then, he ran forward again as though he had seen a comrade in the vacant air; he stretched his arm and waved his staff to the right and to the left. And those who were near enough heard the knocking together of Ezeulu's staff and another which no one saw. At this, many fled in terror before the priest and the unseen presences around him. (p. 70) 
The writer's intention in linking African dignitaries with terror and horror is quite clear in the account. One may be deceived in thinking that the author is here celebrating a vibrant African culture. The events of the plot are crafted to dismantle this superstitious and pseudo-magical display as he soon decentres the protagonists and permits the ascendency of Christianity.

\section{White and Black Daguerreotypes}

Conrad's daguerreotypes of whiteness and blackness are replicated by Achebe with almost identical precision. The colonial encounter was generated through discourses that presented the white race as superior and the black as inferior. Many scholars have striven to disprove this dialectical structure as preposterous and yet it lingers in the consciousness of both races. Both writers present the white as superior and the black as inferior. The white is master, because he can come and go, and often with the risk of life. As Barthes (1990, p. 128) put,

We have already divined the image of the black taking shape behind this tonic little tale: first of all, the black is frightening and he is a cannibal. If we find Bichon heroic, it is because he in fact risks being eaten.

Kurtz's heroism is seen in the risks he accepts, but moreover, in the masterly control of an environment that is enigmatic. He succumbs to the environment, finally giving his life for the ideals he holds. The black on his part must allow the self to be led, instructed, sacrificed, or be obsolete. Ezeulu and Oduche in Arrow of God very much like Nwoye in Things Fall Apart, are willing to sacrifice their rudimentary cultural values and strive for reciprocal recognition in the white master. This is strengthened by the association made between Ezeulu and a race that resembles the Caucasian race. A man of flexible will like Ezeulu cannot simply be black. An important indicator that suggests Achebe's authorial wish to identify with the colonizer is the racial proclivity between Ezeulu and Winterbottom. One may question the extent to: Which Ezeulu's physiological resemblance to the white man translate with his wish to appropriate the other? Why would the author suggest his affiliation to a non-negroid race? This is a strain that has important synechdochical functions in the novel. Ezeulu may not be "black" after all but an earlier species of colonizers suggesting his willingness to risk the tradition, which he encapsulates for the ostensibly more sophisticated one. Winterbottom suggests their mutual recognition as partners in the greater scheme of civilization when he realizes a marked difference between Ezeulu and other Africans by concluding,

One thing you must remember in dealing with natives is that like children they are great liars. They do not lie simply to get out of trouble. ... Only one man - a kind of priest-king in Umuaro-witnessed against his own people. ... But he was a most impressive figure of a man. He is very light in complexion, almost red. One finds people like that among the Ibos. I have a theory that the Ibos in the distant past assimilated a small population of non-negroid tribe of the same complexion as the Red-Indians. (p. 38)

Winterbottom and Ezeulu may be thought to be part of the same civilizing mission in their need to forge another kind of society.

Both writers are also complicit in representations of darkness and the African night is represented as spectral and macabre to the white imagination. Striking descriptive passages are found in both writers and since Achebe is Conrad's successor, one is tempted to assume that he replicates Conrad. Marlow describes the African night as spectral and enigmatic,

We penetrated deeper and deeper into the heart of darkness. It was very quiet there. At night, sometimes the roll of drums behind the curtain of trees would run up the river and remain faintly, as if hovering in the air high over our heads, 
till the first break of day. Whether it meant war, peace, or prayer we could not tell. (p. 43)

Achebe presents an almost word verbatim replica of this passage in his description of Winterbottom's heroic confrontation with the harsh environment. His admiration for the regent is evident in the overall structure of the story buttressing the author's suspicion that he is replicating Conrad. As Winterbottom sleeps at night, he thinks of the African night in this reminiscence,

After the first stretch of unrestful sleep, he would lie awake, tossing about until he was caught in the distant throb of drums. He would wonder what unspeakable rites went on in the forest at night, or was it the heart-beat of the African darkness? Then, one night he was terrified when it suddenly occurred to him that no matter where he lay awake at night in Nigeria the beating of the drums came with the same constancy and from the same elusive distance. Could it be that the throbbing came from his own heat-stricken brain? (pp. 29-30)

What is fascinating is that both Marlow and Winterbottom suggest that the sounds may as well be emanating from their own dark hearts. Conrad writes,

Yes, it was ugly enough; but if you were man enough you may admit to yourself that there was in you just the faintest trace of a response to the terrible frankness of the noise, a dim suspicion of there being a meaning in it which you-you so remote from the night of ages - could comprehend. (p. 44)

Achebe replicates this by writing, "Could it be that the throbbing came from his own heat-stricken brain." The two writers here seem to share the view that the spectral night is something not simply external to the characters but probably part of their own dark yearnings. What strikes me is the similitude that follows in Achebe's narrative even though he would wish to make it known that he is countering Conrad.

This daguerreotype of darkness is integrally connected to tropical diseases that plague not just the European but the Africans as well. In Things Fall Apart, Unoka, Okonkwo's father, develops a stomach disease and is left to perish in the evil forest. Unoka's death is supposed to be caused by spirits and this is again demonstrated in Arrow of God when Ogbuefi Amalu is struck by an incurable disease believed to be caused by spirits (p. 110). What both men do to the spirits to merit this is unspecified and forces one to suspect the African's inability to diagnose diseases, and therefore, the high rate of ignorance that pervaded the society. In Arrow of God, Europeans are struck by malaria as we witness in the death of John Mcmillan and the hospitalisation of Winterbottom. Achebe may once more be simply replicating the disease stricken Africa that Conrad portrays. Kurtz dies from an unspecified disease, probably malaria.

\section{Writing and the Book Daguerreotype}

An even greater image that features in the work of both writers is the idea of writing and the book. Both writers acknowledge colonisation as integrally linked to the idea of writing in the sense that writing facilitated the enterprise. Marlow discovers a worn out book on seamanship by a certain Towzer or Towson and is mesmerized by the find,

The dwelling was dismantled, but we could see a white man had lived there not very long ago. There remained a rude table - plank on two posts; a heap of rubbish reposed in a dark corner, and by the door I picked up a book. It had lost its covers, and the pages had been thumbed into a state of extremely dirty softness. ... Not a very enthralling book; but at the first glance, you could see there a singleness of intention, an honest concern for the right way of going to work, which made these humble pages, thought out so many years ago, luminous with another than a professional light. ... Fancy a man lugging with him a book of that description into this nowhere and studying it — and making notes — in cipher at that! It was an extravagant mystery. (p. 46) 
The worn out book is not just a relic of the past that serves as a luminary in the present and the work also includes marginalia from the previous reader. Kurtz is also concerned about the scribbling he has made falling in the wrong hands and his scribbling in the jungle is a thing of great concern after his death:

One morning, he gave me a packet of papers and a photograph — the lot tied together with a shoe string. "Keep this for me," he said. This noxious fool (meaning the manager) is capable of prying in my boxes when I am not looking. (p. 86)

Greenblatt (1991, p. 57) commented on the primacy of writing in the western imagination by reporting how Christopher Columbus used writing in order to subjugate Caribbean tribes. Columbus' culture did not trust verbal testimony, because its judicial procedures require written proofs, he makes certain to perform his speech acts in the presence of the fleet's recorder. Hence, ensuring that everything would be written down, and consequently, has greater authority.

Achebe replicates this probably because of his conviction that writing and the book are necessary in ridding his society of complacency. Things Fall Apart involves the decampment of the hero's son to Christianity, which is closely connected to the sacred text, the Bible, and education. He is here rejecting his society and embracing writing and the book. Curiously, the novel ends with the district commissioner planning to write a chapter about Okonkwo in his book The Pacification of the Primitive Tribes of the Lower Niger ( $\mathrm{p}$. 150). At the end of Things Fall Apart, the colonial regent sees the necessity to write a paragraph on Okonkwo's suicide, while the Umoufia are unwilling to remember and represent him. Denying Okonkwo an honorable burial is refusing to remember him even as an example to deter others. Achebe sees this dearth in representation among his kin and embraces the colonial regent's capacity to represent the story in writing. Here, again, we witness wonder in the gaze of the subject who must appropriate the master. The man who is perhaps the greatest among his nation is to be buried as a pariah and represented by the enemy while his own people are eager to obliterate his memory.

Achebe chooses to remember Okonkwo by following the example of the district commissioner, and therefore, attempts to wrest the power of representation from the master to the subject. Franz Fanon (1952) argued that colonization was permitted partly by the absences in African cultures, so that in many respects colonization was welcomed, "Not all peoples can be colonized. Wherever Europeans have founded colonies of the type we are considering, it can safely be said that their coming was unconsciously expected, even desired by the future subject peoples" (pp. 78-79).

It is not completely false to argue that in the context of Arrow of God Ezeulu was expecting the European, especially as we are told that news of their exploits and the destruction of the Abam had reached them hitherto. Edward W. Said (1979) had commented on this African powerlessness vis-à-vis the West when he suggests that the West could represent, and therefore, define the East as they found fit partly because of the inability of the East stopping them. Achebe suggests that only by writing can the exploits of great Africans be remembered and by so doing welcomes writing and its accompaniments. In his oeuvre, the West is therefore welcomed, even expected, so that its arrival is in many respects anticipated. That part of the Occident that is civilizing, that checks even its own polity from total degradation was welcomed.

To underscore this writing daguerreotype, this same book The Pacification of the Primitive Tribes of the Lower Niger features in Arrow of God as a text informing the experience of administering the Africans. Tony Clarke is seen reading a borrowed copy of the same title by a certain George Allen. The significance of this picture comes more forcefully when Achebe makes the link between writing and its accompaniments as central 
to power. Ezeulu, the hero, is seen sending his son to learn the art of writing in order to rise above the limits of his culture. He says to Udoche who responds with marked perspicacity, "You must learn it (writing) until you can write it with your left hand." In Conrad, we see the fascination of exporting the written word into the dark margins of the world, and in Achebe, we see the perspicacious appropriation of the lettered word. As Mudhimbe (1988, p. 46) suggested three major figures from the fifteenth century to the end of the 19th, determined modalities and the pace of mastering, colonizing, and transforming the Dark Continent: the explorer, the soldier, and the missionary." Conrad presents us the explorer/merchant while Achebe presents the soldier and missionary. Both of them accentuate the dialectics that informed the colonial enterprise. However, there is an urge for balance in Conrad that is absent in Achebe.

\section{Conclusions}

As one of the most critically received writers in black Africa, Chinua Achebe's works are often read as counter narratives. There is a critical unanimous postulant of his work as deconstructing Colonialist prejudices on black Africa and its cultures. Major critical voices on African literatures and culture have taken and popularised this stance to the extent that Achebe is often read in dichotomy with writers like Conrad. The author find this interpretation seriously flawed when one takes a closer look at what the author have captioned in this paper "daguerreotypes" in the works of the two writers that have been used to popularise this stance. In placing their works side by side, the author seeks to dispel this notion that the two writers are diacritical and put to rest a long standing debate.

Conrad's influence on Achebe is more than simply incidental. This paper suggests that one served as precursor to the other who kept the flame by raising and perhaps substantiating the signs and codes of the other. By raising representations of darkness, decapitation, anthropophagi, and the centrality of writing in the colonial enterprise presented in Conrad's Heart of Darkness and replicated with even greater precision in Achebe's Things Fall Apart and Arrow of God, the author put to rest the debate that has vexed postcolonial studies for so long. The humble wish is that my poor elocution goes the long way to satisfy this audacious ambition.

\section{References}

Achebe, C. (1958). Things fall apart. Oxford: Heinemann.

Achebe, C. (1964). Arrow of god. Oxford: Heinemann.

Achebe, C. (1972). Interview with Lewis Nkosi. In D. Duerden \& C. Pieterse (Eds.), African writers talking (pp. 3-17). London: Heinemann.

Achebe, C. (1995). Named for Victoria, queen of England. In B. Ascroft, G. Griffiths, \& H. Tiffin (Eds.), The post-colonial studies reader (pp. 190-193). London: Routledge.

Achebe, C. (2000). An image of Africa. In D. H. Richter (Ed.), Falling into theory (pp. 323-333). New York, N.Y.: Bedford/St. Martin's.

Achebe, C. (2009). The education of a British protected child. New York, N.Y.: Alfred A. Knopf.

Akyeampong, E. (2014). The assault on culture: Achebe and the crisis of identity in colonial Africa. In N. A. Clarke \& J. Currey (Eds.), Chinua Achebe: Tributes and reflections (pp. 71-80). Banbury: Ayebia Clarke Publishing Ltd..

Ashcroft, B., Griffiths, G., \& Tiffin, H. (1989). The empire writes back (2nd ed.). New York, N.Y.: Routledge.

Barthes, R. (1990). Bichon and the blacks. In D. T. Goldberg (Ed.), Anatomy of racism (pp. 127-129). Minnesota: University of Minnesota Press.

Barthes, R. (1994). The death of the author. In D. H. Richter (Ed.), Falling into theory (pp. 222-225). Boston: Bedford Books.

Bello-Kano, I. (2014). Chinua Achebe: A dissenting opinion. In N. A. Clarke \& J. Currey (Eds.), Chinua Achebe: Tributes and reflections (pp. 112-118). Banbury: Ayebia Clarke Publishing Ltd..

Bloom, H. (1974). The anxiety of influence: A theory of poetry. New York, N.Y.: Oxford University Press. 
Conrad, J. (2007). Heart of darkness. In O. Knowles \& R. Hampton (Eds.), The Congo diary. London: Penguin Classics. Davidson, B. (1992). The black man's burden: Africa and the curse of the nation state. Suffolk: James Currey.

Fanon, F. (1952). Black skin, white masks. (R. Philcox, Trans.). New York, N.Y.: Grove Press.

Greenblatt, S. (1991). Marvelous possessions: the wonder of the new world. Chicago: University of Chicago Press.

Harris, Wilson. (2000). The Frontier on which heart of darkness stands. In D. H. Richter (Ed.), Falling into theory (pp. 334-339). New York, N.Y.: Bedford/St. Martin's.

Killam, D., \& Rowe, R. (Eds.). (2000). The companion to African literature. Oxford: James Currey.

Lazarus, N. (2004). Introducing postcolonial studies. In N. Lazarus (Ed.), The Cambridge companion to postcolonial studies (pp. 1-16). Cambridge: Cambridge University Press.

Marx, J. (2004). Postcolonial Literature and the western literary canon. In N. Lazarus (Ed.), The Cambridge companion to postcolonial studies (pp. 83-96). Cambridge: Cambridge University Press.

Mbembe, A. (2001). On postcoloniality. Berkeley: University of California Press.

Mudhimbe, N. H. (1988). The invention of Africa. Bloomington: Indiana University Press.

Naipaul, V. S. (2010). The masque of Africa: Glimpses of African belief. London: Picador.

Njeng, E. S. (2008). Achebe, Conrad, and the postcolonial strain. CLC Web: Comparative Literature and Culture, 10(1). Retrieved March 7, 2015, from http://docs.lib.purdue.edu/clcweb/vol10/iss1/3

Njeng, E. S. (2013). Achebe's work, postcoloniality and human rights. CLC Web: Comparative Literature and Culture, 15(1). Retrieved March 7, 2015, from http://dx.doi.org/10.7771/1481-4374.1989

Pratt, M. L. (1992). Imperial eyes: Travel writing and transculturation. London: Routledge.

Said, E. W. (1979). Orientalism. New York, N.Y.: Vintage.

Said, E. W. (2003). Freud and the non-European. London: Verso.

Sewlall, H. (2006). Masquerading philanthropy: Conrad's image of Africa in “An outpost of progress." English Academy Review, 23(1), 4-14.

Shoumatoff, A. (1988). African madness. New York, N.Y.: Knopf. 